\title{
RIDING FOR THE DISABLED
}

\section{BELINDA SAMPSON*}

'n Kort oorsig van die geskiedenis en doelstellings word gegee. Terapeutiese effekte word genoem en die vryetydsontspanning word beklemtoon. Die ontwikkeling in Suid-Afrika word beskryf. Die voordele word opgesom en adresse in Suid-Afrika gegee.

The concept of Riding for the Disabled emerged in the early 1950's when Danish born Mme. Lis Hartel, severely disabled by poliomyelitis, won a silver medal for Dressage at the 1952 Olympics. This encouraged others to take up the cause for disabled riders and

* Chairman, S.A. Riding for the Disabled Association. during the middle 1950's several groups were started in Great Britain, leading to the formation of the Riding for the Disabled Association in 1969.

Today there are over 9500 disabled riders in Britain alone, and associated member groups exist throughout Europe, America, Canada, Australia, New Zealand and South Africa.

The Association is a non-profit-making organisation and its aim is to provide riding for wheelchair-bound, crutch-bound and other physically disabled persons and for some cases of mental disability. The following types of disability have been accepted: cerebral palsy, spina bifida, disseminated sclerosis, muscular dystrophy, multiple injuries (including thalidomide-induced de- 
formities), mentally handicapped, blind, deaf and autistic.

Why riding for the disabled? Too often disabled children lead over-protected, sheltered lives and miss out on activities normally experienced by children. Horse riding is both fun and recreation for all children, and, correctly taught, can be of enormous psychological and physical benefit for disabled children. For this reason it is very important that instructors have the close co-operation of physiotherapists and occupational therapists and, in the case of mentally handicapped children, the presence of a member of staff of the centre concerned.

To quote Miss Rosemary Lane, Principal of the School for Physiotherapy in Aberdeen: "Physiotherapists have a vested interest in activity, particularly when it leads to a potential for recreation. Activities produced in the physiotherapy department do not have the ability to produce the enormous potential for recreation found in riding. We should try to enable the children and the young adults to take their place in the comlunity. At its lowest, Riding for the Disabled brings he community in contact with the handicapped; at its highest it enables the handicapped to compete and act normally in the community on a pony. At any level it teaches all of us new skills and disciplines. The contact between the two sections is invaluable

Riding is an achievement, however handicapped the rider, and our main aim is to teach the disabled child to ride as well as he is able to, within his limitations. It may result in physical improvement, but this is not always possible and should not be the yardstick for measuring progress.

Children with disabilities such as athetosis and cerebellar dysfunction definitely show an improvement in balance and co-ordination. The pony provides an unstable base which requires the child constantly to adjust his balance in order to stay in contact with the saddle. All balance responses are related to correction of error and it is important for the helpers to allow just the right degree of insecurity for errors to occur, but not so much that too much tension results.

It has been stated that one of the main benefits for spastic riders is to "overstress" the spastic muscles and let "tiredness" overcome the spasticity. There is no doubt that riding gives these children relaxation and parents and pupils themselves often comment on how onfidence and control gained at riding sessions appear $f$ carry over into normal daily activities. Motivation towards riding is, with few exceptions, strong and may also result in increased motivation towards other activities.

Hyperactive children benefit through learning that they have to control themselves before being able to control their ponies, whilst the three-dimensional movements required in riding help some children to relate their own bodies to the space about them.

Autistic children tend to be very preoccupied with themselves and find it difficult to respond to verbal instruction. However, with repetition and bodily guidance, progress can be made and an important factor is that they sometimes do form attachments towards a pony or helper:

Psychologically all these children gain confidence from participating in a sport normally the province of the able-bodied and the fact that they are brought into contact with adults and adolescents who are not in daily contact with the disabled, widens their horizons. Involvement with the riding world opens the door to spectator participation and interest in sports such as show jumping, polo and horse racing, and this alone means a lot to those normally confined to their

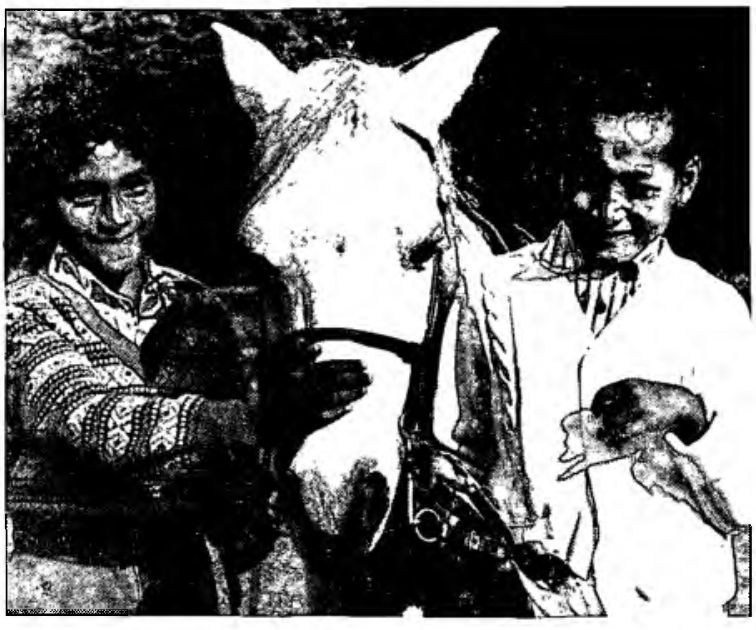

Fig. 1. Two pupils from Eros School get to know their pony.

wheelchairs at home.

In South Africa the concept of riding for the disabled is still new and the first group was started in Cape Town in 1974. Today the group is an Associated Member Group of Riding for the Disabled (U.K.) and there are other centres in Port Elizabeth and Durban. In Krugersdorp a group of therapists take children from the West Rand Cerebral Palsy School to a local riding school.

The Cape Town association operates from stables in Philippi where they have seven ponies of their own and teach an average of 55 pupils per week. At present these pupils come from the Vista Nova Cerebral Palsy School, the Eros School for Cerebral Palsied children, Sunnyday Centre, the School for Autistic Children and the Mary Kijn School for Partially Deaf Children. The Association is currently negotiating for permanent premises more centrally situated, where it is hoped they will be able to include the blind and mentally retarded as well as the many children already on the waiting list.

The Association has two experienced riding instructors, a team of knowledgeable helpers, drivers and the advice and assistance of doctors, orthopaedic surgeons, physiotherapists and occupational therapists. The ponies are carefully selected and strict safety methods observed. There is a comprehensive Third Party Insurance.

Classes for cerebral palsied children are run very much on normal riding class lines. All lessons commence with exercises but pupils will have been assessed, their therapists consulted and the exercises, whilst basically the usual riding exercises, will have been modified to suit each child's particular needs.

Ataxics and mild athetoids start a class by pulling down really hard into the saddle, with the feet in the stirrups, to get pressure down through the spine and legs whilst all spastic quadriplegias, diplegias and spastic quadriplegias with athetosis start with extension and rotation exercises, e.g.

(i) Both hands stretching upwards into the air, palms facing whilst looking straight ahead bebetween the pony's ears.

(ii) Rotating trunk to left and right until their shoulders are parallel to the pony's spine, the backwards hand flat on the pony's back taking weight, not both arms forwards in line with the shoulders as would normally be the case. 


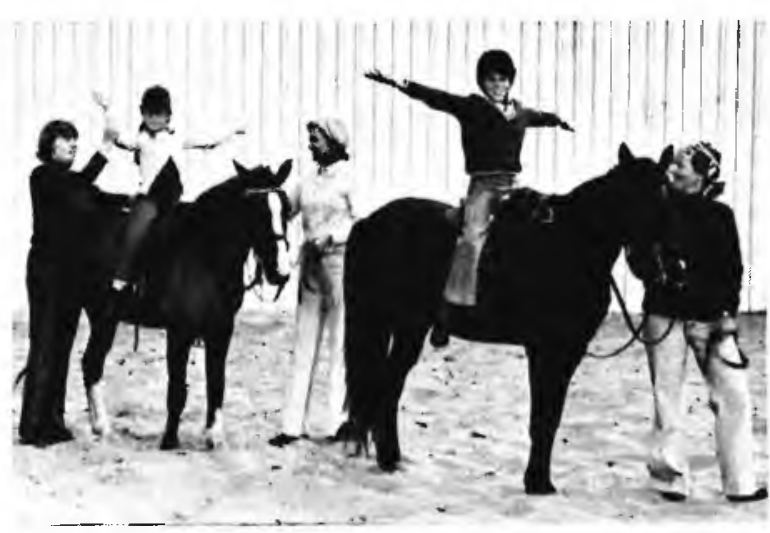

Fig. 2. Helpers assist children from Vista Nova School with the preliminary exercises.

After more exercises along these lines lessons proceed normally. with the children learning to control their ponies at a walk and trot. Most pupils start with three helpers - one leading the pony and one on etther side of the rider but. as a phvsiotherapist in England commented, "One should judge the success of the group not by the number of helpers one uses. but b) the number one can do without!" Ver! few of our pupils now require more than one helper and many can ride their ponics alone.

Although always conscious of the need to have expert physiotherapy advice. we never lose sight of the fact that riding is recreation lor these children and almost always include modified gymkhana games in the lessons. The children oflen go on "out" rides and on rainy days we try to teach them how 10 groom and care for the ponies and tack.

The childrens' joy and interest in riding is evident In their smiling faces and the eagerness with which they attend each session, and the benefits can be summed up as follows:-

(a) Fun and recreation.

(b) An opportunits lo improve balance and coordination. self-discipline and independence.

(c) Emotional and psychological.

(d) A social meeting ground for communication and participation with normal people sharing a mutual interest

(e) The opportunity for contact with a living creature - onc of the most beloved by all children - the pon!

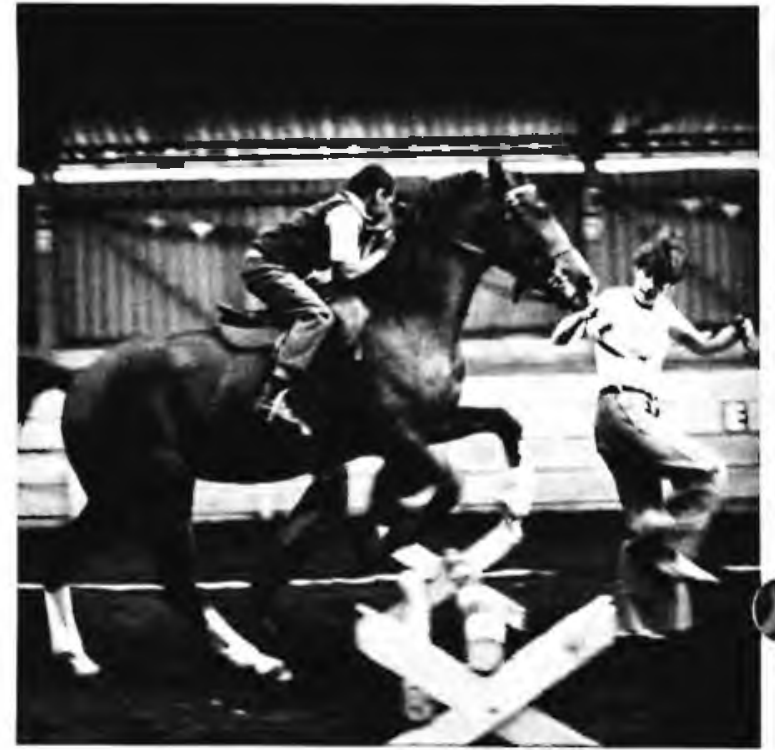

Fig. 3. A young diplegic demonstrates his skill.

Anyone interested in finding out more about the Association and its work should contact:

Cape Town: S.A. Riding for the Disabled. P.O. Box 235. Constantia 7848: phone: Belinda Sampson 021-74-1990 or Joy Finlay 021-74-2236.

Durban: Marie Dawson and Paula Peltz. Stonyhurst Riding School. P.O. Box 297. Hammarsdale 3700.

Krugersdorp: Betlv Proudfool. Elspeth Richardson or Hetta Malan. West Rand School for Cerebral Palsied Children. P.O. Box 792, Krugersdorp 1740, phone 011-665-1267.

Port Elizabeth: Port Elizabeth Riding for the Disabled Association. P.O. Box 15094. Emerald Hill 6011. Organisers: Helen Sunde and Amber Ogden.

\section{References}

1. Annual Journal of the Riding for the Disabled Associalion (1952. 1975).

2. Irwin-Carruthers. S. H.. (1978) personal commune cation.

3. Peacock. G. F. and Sayell. S. Y. (date unknown), Introduction to Riding for the Disabled Association. 